Thomas R. Szydlik

ORCID: https://orcid.org/0000-0002-9345-7960

The Pontifical University of John Paul II in Krakow, Poland

\title{
Imagination and Belief- Newman's Contribution to the New Evangelization
}

\begin{abstract}
As the Church follows the call of John Paul II for a New Evangelization, she must consider how the individual person actually comes to belief. Bl. John Henry Newman, soon to be canonized, addressed this question in An Essay in Aid of A Grammar of Assent. According to Newman, religious belief is not just a logical acceptance of intellectual propositions. It is a commitment of the whole person to God, according to the image of God formed in the person's imagination. (The imagination is that faculty possessed by every human person, which coordinates real life experiences and allows the person to comprehend the real world around him).It is by intentionally employing the imagination, rather than demonstrative logic, that the human person arrives at a belief that is well-grounded, neither cold nor fanatical. Accordingly, our evangelical activity, while never neglecting the truth of the Gospel, should seek to engage the senses and feelings of the human person and not merely the intellect.
\end{abstract}

\section{Keywords}

Newman, Belief, Imagination, New Evangelization.

The announcement of John Henry Newman's canonization has caused excitement among many groups within the Catholic Church. English Catholics, converts to Catholicism, and Oratorians rejoice that one of their heroes is being elevated to the altar. For the rest of the Church, who may not know him as well, 
Newman's canonization offers an opportunity to examine the body of his work and consider its relevance for our own day.

We are all aware that this Third Millennium of Christianity is marked by scandal, but we also know that it was begun with great hope. Pope John Paul II, no stranger to trials and difficulties, foresaw a great "springtime of evangelization," which would transform Catholic Christianity and the world. He believed our Church would come to life, and pointed us toward our most essential work: the proclamation of the Gospel to all the nations.

For our Church to come to life corporately, however, it would be wise for us to consider how we come to belief individually. Indeed, on this topic John Henry Newman has quite a lot to share. In Newman's day, post-reformation apologetics still thrived; for many apologists, Divine Revelation was to be believed especially because of philosophical proofs that preceded the proclamation of God's Word. Newman's thought on the development of belief was different. Instead of abstract, deductive ideas of how the human person ought to arrive at belief in God Newman described how the human person actually arrives at belief. He also explained how the human person could provide a reasonable justification for their belief, even if this justification were not a technical, philosophical proof.

Considering the importance of an understanding of belief for the work of ourtime, I will offer here an explanation of Newman's phenomenology of belief.Relying especially on Newman's An Essay in Aid of A Grammar of Assent, I will discuss imagination and belief in the writings of Newman and consider how his thought can help us to proclaim the Gospel in the 21st century.

\section{Imagination in Itself}

At the heart of John Henry Newman's explanation of belief is the imagination, that faculty possessed by every human person, which coordinates real life experiences and allows the person to comprehend the real world around him. To be clear: "imagination" as used by Cardinal Newman does not follow the typical definition of "imagination." Newman's imagination is not directed toward "imaginary" things; it does not construct fantasy worlds that never have and never will exist. Rather, the imagination serves to grasp reality as the human person perceives it. For Newman, the imagination attempts to make sense of the vast amount of data that the person absorbs in his life; it gives the 
person a sense of order in his experiences and assists him in understanding the real world around him.

To offer another point of clarification: "imagination" and "image" also do not merely refer to that which is visible. ${ }^{1}$ As John Coulson points out, the use of the imagination, as explained by Newman, does not involve a "simple process of 'imaging."' Rather, the imagination provides for the human person a means to become aware of the state of affairs around himself. ${ }^{3}$ This "state of affairs" involves much more than those things which the eyes take in. It includes the impressions that the person acquires by means of his senses, his emotions, his encounters with other persons, and all the other experiences that affect his life.

As a result, the imagination does not directly contribute to (what philosophers might call) the human person's "abstract Aristotelian knowledge." The imagination does not concern itself with concepts and forms. It does not contemplate generalities, and it does not seek to make formal deductions based upon mere ideas. The imagination would not, for example, ponder the abstract notion of "a man." It would, however, be interested in "my nephew Nicholas, the son of my sister Catherine" as I have experienced him. It would not attempt to piece together a more developed concept of him based on notions such as "short in stature," "strong-willed," and " 32 year-old." Instead, through real life experiences of Nicholas, the imagination would consider the reality of who he is in himself and not according to general characteristics that he shares with other people.

The example that I have just provided of the use of the imagination shows how widespread its application can be. Cardinal Newman did not intend to suggest that the human person uses the imagination for only religious matters; its

${ }^{1}$ I readily recognize the potential confusion that these terms could cause in this regard, but due to the use of "imagination" by Newman himself and the fact that "image" seems to be the natural word to use for that which arises from "imagination," I will use these words throughout this thesis.

2 J. Coulson, Religion and Imagination: In Aid of a Grammar of Assent, Oxford: Clarendon Press 1981, 47.

${ }^{3}$ R. Holyer, Religious Certainty and the Imagination: An Interpretation of J.H. Newman, “The Thomist" 50, no. 3 (July 1986), 405.

${ }^{4}$ Clearly, Newman would not deny the importance of abstract knowledge. It is by means of abstractions, after all, that the human person is able to communicate with those around him; the human person relies upon abstractions (or notional apprehensions) from particular experiences to communicate thoughts and ideas to those who have similar abstract concepts resulting from different concrete experiences. 
use extends to all real apprehensions. A real apprehension "is an imaginative grasp of a statement such that what is stated affects the person as though it were a reality in which he is involved." It is the intelligent acceptance of the facts and realities of a person's life. By means of real apprehensions, the human person takes in impressions of the world around him in its concrete rather than abstract details. ${ }^{6}$

Nevertheless, Newman had, as a primary motive for his examination of imagination, the justification of the religious act of faith. For those persons possessing little or no training in formal philosophical deduction, as well as for those with much education in this area, the imagination could be used to consider the "state of affairs" regarding the existence of God, the divinity of Jesus of Nazareth, and the divine establishment of the Catholic Church. The imagination could give the human person an understanding of the reality of these "objects" of his experience, as well as that of all the other circumstances of his existence.

\section{The Formation of Images}

Because the imagination draws its data from concrete experience, the human person does not use it in a "neat and tidy" manner. Unlike Aristotelian apprehension, the human person does not utilize well defined notions to produce perfectly ordered conclusions within his imagination. Instead, the human person forms images using the real experiences of life, which are seldom perfectly defined, fully understood, or absolutely identical with the circumstances and events of those of someone else. In his Apologia Pro Vita Sua, Newman offered a personal example that can show how the human person forms his own unique images based on his own experiences: "Now I come to two other works, which produced a deep impression on me in the same Autumn of 1816, when I was fifteen years old, each contrary to each, and planting in me the seeds of an intellectual inconsistency which disabled me for a long course of years. I read Joseph Milner's Church History, and was nothing short of enamoured of the long extracts from St. Augustine, St. Ambrose, and the other Fathers which I found there. I read them as being the religion of the primitive Christians: but simultaneously with

\footnotetext{
${ }^{5}$ R. Holyer, Religious Certainty and the Imagination, 405.

${ }^{6}$ Newman distinguishes his "real apprehensions" from those "notional apprehensions," which comprise knowledge of the more Aristotelian, abstract sort.
} 
Milner I read Newton on the Prophecies, and in consequence became most firmly convinced that the Pope was the Antichrist predicted by Daniel, St. Paul, and St. John. My imagination was stained by the effects of this doctrine up to the year $1843 . " 7$

Because of the evidences that he had acquired by means of his own reading, Newman formed a unique image of the Papacy. Undoubtedly, a devout Catholic would have formed a vastly different image of the Pope than did the adolescent John Henry Newman, and the Catholic would likely be of the opinion - as would Newman as he grew older - that he needed a more thorough exposure to the Papacy than Milner and Newton provided. This example illustrates then that the human person's experiences of the world are unique, but also that they can be imperfect when taken individually. However precise these experiences may be, the imagination acts as the means by which the person coordinates them into coherent realities; the imagination synthesizes these evidences and concrete data in such a way that the person arrives at an insight into reality that is particular to him and that allows him to live his life accordingly.

As previously mentioned, in hearing the word "imagination" we might think that this faculty only deals with that which is visible, and we might suppose that the only evidence which it takes into consideration is that which the human person can see. In fact, the range of evidences extends much more broadly. Robert Holyer notes that the real apprehensions, upon which the imagination relies are "dependent on our beliefs, our desires, our personalities, our past experiences and our knowledge of ourselves, others and the world... But real apprehension is not only person-related, it is also facilitated by the use of language in specific ways. According to Newman, history, stories, narrative, and the description of facts and people's experiences more readily involve us than do concepts, theories, and abstract ideas."

Although the human person considers much more than what he can see in forming an image in his imagination, Newman does note that much of that which the human person learns by way of the stories and anecdotes tend to be apprehended in a way that appeals more to the vision than to the other senses. The human person can rather easily describe for another person specific physical appearances, movements, textures, and the like, but he falls short of words

\footnotetext{
7 J.H. Newman, Apologia Pro Vita Sua, New York: W.W. Norton and Company 1968, 18.

${ }^{8}$ R. Holyer, Religious Certainty and the Imagination, 405.
} 
in describing the reality of sounds or sensations. ${ }^{9}$ Thus, for example, a man can rather easily describe the physical appearance of his wife, but a woman would have a difficult time describing (at least to a man) the particular pain experienced during childbirth.

Presented with the evidences available to it, the imagination "orders into a unique whole the arguments and pieces of evidence which, up to this point, had existed as mutually exclusive and isolated in their effect on the mind." ${ }^{10}$ Sometimes the process of forming an image occurs with little difficulty because the person has had little experience of a particular person or thing.A student, for instance, might form an image of his teacher as unreasonably strict and ill-tempered solely on first impressions. Later on, this impression might change due to greater experience, but after the first day of class, with no other evidence upon which to draw, the student has little trouble forming an image of his teacher. Unfortunately, in some situations, because of factors outside the control of the human person, a limited amount of experience is all that he has for the construction of an image. As a result, he can be left with rather simplistic, distorted images of reality.

Yet, seldom does an image arise from a single piece of evidence. Often the human person considers a multitude of diverse experiences in forming an image in his imagination, and thus the imagination can exhibit an impressive dexterity in the way that it functions. As an example, Newman noted that those who assent to an image of Jesus' divinity do so based on "various experiences and disposing causes, variously combined; such as a warm or strong imagination, great sensibility, compunction and horror at sin, frequenting the Mass and other rites of the Church, meditating on the contents of the Gospels, familiarity with hymns and religious poems, dwelling on the Evidences, parental example and instruction, religious friends, strange providences, powerful preaching." ${ }^{11}$

From these examples of the limitations and skills of the imagination, we can observe how it assists the human person in coming to a greater understanding of the realities around him. Beyond descriptions of this sort, however, it becomes difficult to speak about the psychological processes that make up its rather mysterious work. While we might have a natural curiosity to find an explanation of the principles and methods that allow the imagination to function as it does,

9 J.H. Newman, An Essay in Aid of A Grammar of Assent, 28.

10 D.M. Hammond, Imagination in Newman's Phenomenology of Cognition, "Heythrop Journal" 29, no. 1 (January 1988), 27.

${ }^{11}$ J.H. Newman, An Essay in Aid of A Grammar of Assent, 86-87. 
Newman makes it very clear that it does not operate according to the standardized methods of logic and inference of formal philosophy. The functioning of the imagination cannot be described by referring to abstract structures found in the mind of every human person.

The formation of images is, in fact, a very personal process. Each human person comes to an awareness of a particular reality around him in his own way, and consequently, the images, which he forms and to which he gives his assent are unique as well. Newman himself stated that the images that arise in the imagination "are often peculiar and special. They depend on personal experience; and the experience of one man is not the experience of another. Real assent, then, as the experience which it presupposes, is proper to the individual... It shuts itself up, as it were, in its own home, or at least is its own witness and its own standard." ${ }^{12}$ As a result of the personal nature of the processes of the imagination, each of two persons experiencing the same object will develop his own particular image of the object. Each will bring his own personal background and dispositions to the consideration of the object, and these considerations along with other factors will affect the image that is formed in his imagination.

This does not suggest that two different people, possessing imaginations that function differently cannot arrive at the same general conclusions regarding an object under consideration. Two people having had dinner together could both have an image of having had a very good meal. One person, however, might find his primary evidence for this in his enjoyment of their conversation, while the other might have been more positively affected by the food itself. As a religious example of this same phenomenon, Newman pointed out that a number of different people may come to realize, through their imaginations, that Jesus of Nazareth is God, but each will have arrived at this conclusion by way of different experiences. "In each case the image in the mind, with the experiences out of which it is formed would be a personal result; and though the same in all, would in each case be so idiosyncratic in its circumstances that it would stand by itself, a special formation." ${ }^{13}$

Whatever the object may be under examination, then, the individual human person in his own way utilizes various evidences to have a unified image in his own imagination. Though in abstract terms and descriptions he might agree with another person regarding the general form of the object, his experience

12 J.H. Newman, An Essay in Aid of A Grammar of Assent, 83-84.

13 J.H. Newman, An Essay in Aid of A Grammar of Assent, 87. 
of this object in his imagination is decidedly his own. The image that he possesses is unrepeatable.

\section{Imagination's effect on the Emotions}

The imagination, as I have previously observed, functions in such a way that it gives the human person a sense of reality as if he were currently experiencing it. Being "really" involved in the images in his imagination, the human person therefore reacts to them in a real way; his entire person is involved, especially his emotions. If, for example, the coherent image presented to him in his imagination is one that pleases him, he obviously finds himself attracted to it. Those images which are unpleasant, even horrifying, can, on the contrary, drive him to seek another reality in which he can find greater peace and joy.

The force of attraction or repulsion of these various images directly depends on the vividness of the particular image. Fresher and more lucid images elicit stronger reactions on the part of the human person. A more coherent image will provoke stronger sentiments than will a jumble of facts; those events in a person's life which he has more recently experienced will generate stronger reactions than will an incident in the distant past. Newman further observed the ability of emotions experienced in the past to perdure in the imagination for a longer period than other evidences. The memory of various events in the life of a person may fade, he noted, but "the vivid image of certain anxieties or deliverances" will never do so. ${ }^{14}$ Consequently, even though the sights and sounds of an event may have long ago departed from the imagination, the feelings of a person may nevertheless be stirred up by those strong feelings of the past that may seem to be a present reality.

In considering the emotional effects of the imagination, the difference between images in the imagination and abstract notions held in the intellect becomes especially apparent. Those ideas which the human person holds in a notional way in his intellect do little to produce excitement, while images can stimulate feelings in a profound way. A preacher, for example, might speak about love in an imaginative or in a notional way and depending on his approach, will call forth very different reactions from his congregation. He may speak about love as "self-gift" or as "mutual self-donation," but if the individuals to whom

${ }^{14}$ J.H. Newman, An Essay in Aid of A Grammar of Assent, 25. 
he is speaking cannot associate these terms with their own personal experiences, they will remain unmoved by the preacher's sermon.If instead, the preacher offers examples of love in story form, such as a husband's devoted care for his dying wife, he can inspire feelings in them and encourage greater interest in the message he is conveying.

With or without the emotions, Newman acknowledges that the human person can make an act of assent to either an image or a notion, ${ }^{15}$ but as Robert Holyer suggests, in Newman's thought the emotions have a significant role to play in the vitality and certitude of this assent. Holyer states that "the strength of conviction produced by arguments that appeal to the imagination is in part derived from the strength of the emotions they evoke... the emotions contribute to a feeling of certainty by lending a sense of reality to the conclusion of the argument."16

\section{Imagination and the Act of Belief}

When an assent involves the whole person in this way (and not just their intellect) Newman refers to it as "real assent." Such an act does not remain impassive as if dealing in abstractions, but rather involves all of the human person and their reality. Because of this, a mature, real assent requires more than mere sentiment as a foundation. Since a real assent can significantly affect the way the human person lives his life, he ought to approach it with profound seriousness. The truth of the object of belief, and not merely the human person's emotions, ought to encourage him to believe. He needs to know not only that the reality to which he assents is pleasing to him but also that it is true.

Can the human person actually establish the truth of these images? According to the rules of strict, logical demonstration, no, ${ }^{17}$ but Newman points

${ }^{15}$ J.H. Newman, An Essay in Aid of A Grammar of Assent, 185.

16 R. Holyer, Religious Certainty and the Imagination, 410-411.

${ }_{17}$ Cardinal Newman noted that for the philosopher John Locke "it is not only illogical, but immoral to 'carry our assent above the evidence that a proposition is true, to have 'a surplusage of assurance beyond the degrees of that evidence." cf. J.H. Newman, An Essay in Aid of A Grammar of Assent, 163. Following Locke's line of thought, without the use of strict demonstration, the imagination cannot provide the foundations for a legitimate act of belief; no truth could truly be established in an absolute way from experiences of the concrete world because nothing and no one could guarantee that these experiences would always corroborate 
out that the human person constantly makes assents to truths that are not firmly established by demonstrable knowledge. The human person must do so in order to live a practical life in this world. Newman notes that like these everyday assents, acts of religious assent also do not require strict demonstration. He further insists that the human person can actually have greater confidence in these religious assents than in most everyday assents because of the numerous evidences to which the person's imagination makes appeal. The image of the religious reality to which the human person assents often develops over time until the person can assent to it as true.

Though mankind has always held in high regard those who have applied themselves to intellectual and academic pursuits, Cardinal Newman observed that in the comprehensive reality of human experience "man is not a reasoning animal; he is a seeing, feeling, contemplating, acting animal." ${ }^{18}$ The everyday life of the human person, in fact, seldom allows him to express himself as a strictly reasoning animal. Before making a decision, he does not normally spend inordinate amounts of time determining if he is making a perfect choice; he very rarely has the time to do so. Instead, to be able to live life in a practical way, the human person must regularly make assents that have imperfect epistemological foundations. Clearly, few of these assents would be labeled as momentous decisions; Newman himself labeled assents of this sort as "simple." In speaking of them he states, "A great many of our assents are merely expressions of our personal likings, tastes, principles, motives, and opinions."19

Acts of religious belief, however, fall typically not into the category of the "simple," but into that of the "complex." The importance of the act of faith, when compared with that of more simple assents, suggests that the human person ought to approach this type of assent differently. The human person certainly cannot approach an act of belief in God in the same way that he decides what to eat for dessert; he cannot decide to believe or not to believe in God solely out of habit or whim. The act of belief in God, because of the effect that it can have on the person's life, calls for a more thorough process of scrutiny to convince the human person of its truth. The human person must appeal to numerous

that truth. Faith would therefore seem to be an irrational leap beyond the facts that are known to the human person.

18 J.H. Newman, An Essay in Aid of A Grammar of Assent,94.

19 J.H. Newman, An Essay in Aid of A Grammar of Assent,188. 
evidences, which his imagination constructs into a more complex image for him to judge.

I have already spoken about the underpinnings for this process when I discussed the way in which images form in the imagination. From the evidences that are presented to the imagination, the human person is able to form an image of the reality to which he assents. As the person is exposed to more and more evidences, he becomes more and more aware of the truth of the image in his imagination. As his experiences of this reality diversify, not only the general form but also the details of the image develop.

In one sense the human person gradually comes to an awareness of the truth of his object of assent; as the image's form and details are completed by real life experience, the person becomes increasingly aware of the image's truth until, having been convinced by the image presented to him, he gives his assent to it. Yet, the awareness of the truth of this image does not arise from a logical, stepby-step reasoning from the individual evidences; the awareness of its truth comes from a perception of this image as an integral whole, to which details may be added. Newman gives the following explanation of this awareness: “... an object of sense presents itself to our view as one whole, and not in its separate details: we take it in, recognize it, and discriminate it from other objects, all at once. Such too is the intellectual view we take of the momenta of proof for a concrete truth; we grasp the full tale of premises and the conclusion, per modumunius - by a sort of instinctive perception of the legitimate conclusion in and through the premises, not by a formal juxtaposition of propositions." ${ }^{20}$

Cardinal Newman's phenomenology of belief therefore avoids two significant dangers to the act of faith: fideism and rationalism. Undeniably, Newman affirms that the human person makes a decision that is not demonstrably supported by the evidence at hand; when dealing with a concrete reality, the human person can never exhaust all the ways in which to experience it. The "leap" that his phenomenology proposes, however, is far from the blind leap of fideism; the person's assent is encouraged when he sees the truth of the coherent, albeit incomplete, image of the reality under consideration. At the same time, Newman's phenomenology, while "reasonable" does not base its reasonability on logical deduction. He in no way suggests that the human person can make an act of belief in Christianity from anything other than his experiences of religious

${ }^{20}$ J.H. Newman, An Essay in Aid of A Grammar of Assent,301-302. 
realities and revelation; Christianity's truth cannot be strictly demonstrated by philosophy.

Specific examples in our day seem to confirm Newman's insight into the importance of the imagination in making an act of belief. In particular, I would like to offer my own experiences of encounters with profoundly convinced converts to Catholicism. When I have spoken with these converts or listened to the description of their assent to Catholicism, they have often mentioned a particular article of faith that was especially influential in their decisions; the Real Presence of Christ in the Eucharist has perhaps been the most common motive that they have cited. At the same time, I have often heard evaluations by them that Catholicism "makes sense" or that it "all fits together." Comments such as these suggest to me that in assenting to the truth of the Catholic Church, converts often consider a large amount of evidences in forming the image of Catholicism to which they assent. The zeal with which many converts to Catholicism live their lives ${ }^{21}$ also suggests that for them the truth of the Catholic Church is not only an intellectual concern but is something that impacts their lives in a concrete way and is something to which they wish to respond. The assent which they have made, though it may be very reasonable, is far from logically deductive. It is very much real.

When the human person makes a real assent to a religious object, his life does not of necessity have to express this. Yet, as the previous example of Catholic converts implies, the imagination of the human person often encourages him to relate toward an image as if it were a substantial reality; he reacts in a real way toward the state of affairs presented by his imagination. This reaction often involves the stimulation of the human person's emotions, and these emotions can lead him to live according to his imagination in practical ways.

While it is true that particular images may have no emotional, and therefore nopractical effect on a particular person, ${ }^{22}$ the emotional effect of the imagination reveals a major difference between notional and real assent in the thought of Cardinal Newman. John Coulson points out that "Newman grounds his conception of notional and real assent upon this distinction between what might be called an armchair nod of assent and the decision to go and do something

${ }^{21}$ I would like to point out the efforts of former Protestant ministers, such as Dr. Scott Hahn and Jeff Cavins, who now dedicate much of their lives in speaking passionately about the importance of Catholicism to them.

22 J.H. Newman, An Essay in Aid of A Grammar of Assent,89. 
about it." ${ }^{23}$ Notional assent, dealing with abstract concepts and generalities, does not normally inspire the human person to act according to them. Conversely, real assent, dealing with images of real objects and experience, can urge the human person to respond to his understanding of reality in practical ways. As Newman observed, "No one, I say, will die for his own calculations: he dies for realities." ${ }^{24}$

\section{Mistaken Assents to Mistaken Images}

In our day and age, however, it has become abundantly clear that those who die for realities are not exclusively Christian. The modern day threat of terrorism has provided a striking example of how real assents can be made to images in the imagination that are vastly different from those of Christianity. The actions of terrorists (who also carry out their deeds "in the name of God") differ considerably from the actions of the Apostles and martyrs; their actions, when contrasted with those of Christian heroes, suggest that real assents can be made to mistaken images.

Cardinal Newman, in speaking about real assent does not seem to deny the possibility that the human person can make a mistake about the veracity of an image in his imagination. He states, "The fact of the distinctness of the images, which are required for real assent, is no warrant for the existence of those objects which those images represent." ${ }^{25}$ An image may be distinct to the human person because he has had a very limited number of evidences to consider in the images formation. In addition, these evidences may be all of the same sort and indicate an image that is "black and white," with few "gray areas." When the human person sees this apparent lack of inconsistency in an image and finds his emotions aroused by it, he can very easily offer his assent to it.

This assent to mistaken images is particularly noticeable when the human person develops prejudices. The person who holds a prejudice against a particular person or group does so because he has developed a facile image of that person or group. His image is not ambivalent, and therefore his emotional reaction to the image is not ambivalent, either. He does not have enough evidence

${ }^{23} \mathrm{~J}$. Coulson, Religion and Imagination, 46.

${ }^{24}$ J.H. Newman, An Essay in Aid of A Grammar of Assent, 93.

25 J.H. Newman, An Essay in Aid of A Grammar of Assent, 80-81. 
to arrive at a more precise image of the reality he experiences, but, encouraged by his emotions, which lend a sense of reality to the image in his imagination, he assents to this mistaken image as true. Newman observes that prejudices are "founded upon reports of facts, or on arguments, which will not bear careful examination. Such was the disgust felt towards...the Christians of the first centuries, as a secret society, as a conspiracy against the civil power, as a set of mean, sordid, despicable fanatics, as monsters reveling in blood and impurity." ${ }^{26}$

Rather unfortunately, the Catholic Church of the $21^{\text {st }}$ century seems to be an object of modern day prejudice as well. It takes little effort to perceive the negative light in which the Catholic Church is held by many people in our world. Yet, the critiques of the Catholic Church often sound rather simplistic and undeveloped: "The Catholic Church hates women," "The Catholic Church needs to get with the times," "The Catholic Church hates gays," "The Catholic Church has a repressed view of sex," and so on. Criticisms such as these suggest that those who offer them have not thoroughly examined their image of Catholicism and have not considered that a 2,000 year old organization could have a more nuanced identity than their image suggests.

It is this examination, or the lack thereof, that John Coulson points to in order to indicate the difference between a fanatic and a profoundly convinced believer: "The fanatic is so often the man of one idea; illusions do not last." ${ }^{27}$ The illusions do not last, that is, when subjected to careful study. If the fanatic takes time to broaden his experiences of the object under consideration, he can come to realize the fuller reality of this object. He can arrive at a calmer, more secure awareness of the truth of the image in his imagination, or he can realize that he has assented to a mistaken image that needs a radical reformation. He merely needs to open himself to an active scrutiny of the image in his imagination.

Yet, many people with mistaken images, do not make an effort to examine them. The reasons for this lack of scrutiny depend upon the person. Laziness and disinterest certainly seem to affect some. Others are more likely to be influenced by the emotions arising from their imagination. Some of these individuals, who might be considered more fanatical, seem already to have been "convinced" by their image and do not wish to be "bothered by the facts" of further experiences. Others appear to have been discouraged by their image and feel little encouragement to understand it further. Whatever the reason may be, many

\footnotetext{
${ }^{26}$ J.H. Newman, An Essay in Aid of A Grammar of Assent, 254-255.

$27 \mathrm{~J}$. Coulson, Religion and Imagination, 68.
} 
people never take the opportunity to understand the reality around them more fully and therefore never come to a certitude either that their perception of reality is true, or that they could arrive at the truth.

\section{Certitude}

In spite of the many examples of people who have made mistaken assents, Cardinal Newman insists that the human person can come to certitude about those things in which he believes. In discussing certitude, Newman emphasizes that the human person need not appeal to abstract reasoning in order to have a sense of security in his real assents. Rather, using the same imagination that led him to believe, the human person can assure himself that his assent is not mere prejudice; he can investigate the evidences for his belief to reconfirm his assent, if necessary he can inquire whether or not he assented to a mistaken image, and through a greater and greater accumulation of evidences he can become certain of the reality of his belief.

As the images in the imagination encourage the human person to believe, so too these same images assist the human person in becoming certain of his belief. Unlike simple assent, however, where one piece of evidence can provide a simple and attractive image in which to believe, certitude requires a multitude of evidences. The human person arrives at certitude "by a conviction growing out of a 'mass of probabilities," 28 and as in the process of coming to assent, those evidences that convince him are particular to him. Over time, as the evidences to support a particular image continue to accumulate, the human person becomes more and more certain that he has made a legitimate assent. Newman likens the strength in certitude from these various evidences to that of a cable which "is made up of a number of separate threads, each feeble, yet together as sufficient as an iron rod." ${ }^{29}$ The person might not be able to provide a single, definitive philosophical proof for his assent, but the number of evidences at hand gives him that particular repose of the mind that comes along with being certain. ${ }^{30}$

28 R. Holyer, Religious Certainty and the Imagination, 409.

29 A letter of 1864 quoted in Wilfred Ward, The Life of John Henry Cardinal Newman, vol. 2 (London: Longmans Green, 1912), 43.

30 J.H. Newman, An Essay in Aid of a Grammar of Assent, 204-205. 
Here we find the fundamental distinction between an assent that is certain and one that is mere prejudice. The person who is prejudiced has taken a somewhat limited number of evidences into consideration in forming the image to which he assents. The person who is certain of his assent, on the contrary, has used a diverse number of experiences to form his image. This contrast of prejudice and certitude does not deny that it is hypothetically possible for a person to have developed a false image of an object while having spent time examining it. Yet, as Newman notes, in the life of the human person, "it is rare that what is not true should be so free from every circumstance and token of falsity as to create no suspicion in his mind to its disadvantage, no reason for suspense of judgment." ${ }^{31}$ The likelihood for the human person to maintain a false image in his imagination after a meticulous examination is rather slim. Its continued existence after having been formed seems to result much more often from a failure of the human person to evaluate it.

Cardinal Newman does admit that occasionally the human person can be led to withdraw a complex assent which is more than mere opinion. Sometimes, in spite of the vast amount of evidences that have been coordinated by him, crucial evidence is still lacking to the person; this evidence can be so contradictory to the image in the person's imagination that he needs to withdraw his assent and reform his image. Yet, isolated cases of failures in certitude do not, according to Newman, require the human person to be suspicious of certitudes in general. He states that for the human person "no instances then whatever of mistaken certitude are sufficient to constitute a proof, that certitude itself is a perversion or extravagance of his nature. We do not dispense with clocks, because from time to time they go wrong and tell untruly. A clock, organically considered, may be perfect, yet it may require regulating." ${ }^{32}$ As the human person grows and corrects both simple and - less frequently - complex assents, he learns to regulate himself; he discovers what has led him to make mistaken assents in the past and consequently he is much less likely to commit them in the future.

\footnotetext{
31 J.H. Newman, An Essay in Aid of a Grammar of Assent, 196-197.

32 J.H. Newman, An Essay in Aid of a Grammar of Assent, 233.
} 


\section{Imaginative Evangelization}

Cardinal Newman had great confidence in the ability of the imagination to lead the human person to belief and certitude in the Christian religion. He held this conviction because he had seen it at work in himself and in others. As we consider our need to evangelize in this Third Millennium, then, it would be wise for us to consider using those methods and techniques that would most activate the imaginations of those whom we wish to lead closer to Christ. The brief examples that I will offer are certainly not exhaustive of these methods, but they should indicate an important pathway for evangelization in the future.

Our preaching should be descriptive. Abstract Greek philosophy certainly has its place, but it is probably not in the pulpit. Jesus spoke in parables, Newman would likely argue, because they appealed to the imagination. To understand and embrace the Gospel, men and women of our age need vivid examples of how one is to live as a follower of Jesus. "Descriptive" does not, however, mean "insubstantial." In recent decades the West has seen a proliferation of books of "homily stories" that are not rooted in sound Christian doctrine. The use of such works should be admonished not just as an offense to the Christian message but as an abuse of the human person's imagination.

Our churches should be beautiful. Many non-believers people encounter Catholicism when they attend weddings and funerals of friends or when they explore foreign cities; how important it is that these encounters leave them with an image of awe and mystery surrounding the worship of the Triune God. Whether a church building's decoration is simple or ornate, it's order and structure, as well as the materials used for its construction, communicate the nature and purpose for its existence. A church building made from poor materials, with a design that fosters an anthropocentric celebration of the Eucharist, can build within the imagination of the inquirer an image of a Church that does not take the Lord seriously. What an awful image to construct! As a Church, our buildings consecrated for worship should be built with the purpose of building an image of the Lord's glory and majesty; our churches should raise the human person's mind and heart to God.

The Church should also continue to promote the value of personal testimony. When a Catholic (clergy or lay) stands up and speaks of what Jesus has done for them, the Christian message ceases to be abstract. There is a profound difference between "Jesus heals" and "Jesus healed me." The second of these phrases sparks the imagination; a person receiving this witness can see that Jesus really works here and today and not just in some theoretical place and time. 
As a Church, we must engage in charitable action. Though most likely not spoken by St. Francis of Assisi, this saying still has merit: "Preach the Gospel, and if necessary, use words." Men and women of our day, having seen the anti-witness of abuse within the Catholic Church, need to encounter Catholics who care for the poor, the weak and the marginalized. They need to see that the message of Christ can be lived and actually is lived. They need their imaginations filled with concrete examples of holy believers, so that they too can be converted and really believe.

Finally, we must constantly bring to the world's attention the lives of the saints. George Weigel referred to Pope John Paul II as a "Witness to Hope," and so he was. In his own life, he experienced the Holy Spirit at work - even in moments of difficulty and trial. Because of that experience, he canonized many others who had been guided through life by the Lord. Our age especially needs to recall that these were men and women of flesh and blood, who, inspired by the Lord, lived heroic lives. We need to remember their wisdom, their charitable deeds, and their struggles to be converted. For us to believe that we can be saints, we need our imagination engaged by the examples of men and women who already are saints. For our purposes, then, what better place to start than John Henry Newman and the man who declared him "venerable," John Paul II.

\section{Bibliography}

Cirarda Lachiondo, Jose M., et al., Credere oggi nel Dio di Gesú Cristo, Lettere Pastorali 1986-1987, Verona: Magistero Episcopale, 1987.

Coulson J., Religion and Imagination: In Aid of a Grammar of Assent, Oxford: Clarendon Press, 1981.

Gallagher M.P., Newman on Imagination and Faith, "Milltown Studies" 49 (2002), 84-101.

Hammond D., Affectivity, Imagination, and Intellect in Newman's Apologia, "Thought" 67, no. 266 (September 1992), 271-286.

Hammond D., Imagination in Newman's Phenomenology of Cognition, "Heythrop Journal" 29, no. 1 (January 1988), 21-32.

Holyer R., Religious Certainty and the Imagination: An Interpretation of J.H. Newman, "The Thomist"50, no. 3 (July 1986): 395-416.

Newman J.H., An Essay in Aid of A Grammar of Assent, London:Longmans, Green and Co., 1924.

Newman J.H., Apologia Pro Vita Sua, New York: W.W. Norton and Company, 1968.

Newman J.H., Fifteen Sermons Preached Before the University of Oxford, London: Longmans, Green and Co., 1909.

Ward W., The Life of John Henry Cardinal Newman, Vol. 2. London: Longmans Green, 1912. 